\title{
Les fees ont soif: Feminist, iconoclastic or blasphemous?
}

\section{Maria-Suzette Fernandes-Dias}

In his 1993 book, Blasphemy, David Lawton is of the opinion that blasphemy in the arts is healthy because it 'often registers the irruption of a new reading community $^{\prime}$ and marks such a community's rite of passage. Women's writing has been an important site of blasphemy in the twentieth century. Blasphemy has provided a formerly marginalised group with a medium though which to assert its rights against an existing social and cultural order that abhors transformation and resists it. It does this by wielding the power of religious constructs about the sacrosanctity of dogmas and beliefs, the naturalness of civil codes of ethical and moral propriety, and the necessity of judicial provisions like repressive censorship and blasphemy laws. This chapter examines a literary scandal that marked Quebec's rupture from traditionalism and religious institutionalism, and the emergence of its post-Quiet Revolution feminine identity.

The scandal of Les fees ont soif erupted in 1978 - more than a decade after the Quiet Revolution (1960-66) and Quebec's rejection of traditionalist spiritual values, classical education, church-controlled and inspired social welfare institutions and its rural, agricultural heritage, and its assertion of a new Quebecois identity. Feminine emancipation was still in its embryonic stage. The Catholic Church, despite its waning political clout, exercised nevertheless, considerable influence on the behaviour of women. ${ }^{2}$ A decade of secular outlook had not been long enough to dismantle traditional constructs about the role of women and centuries of cultural and social conditioning about male superiority, or to undo the imposing omnipresence of retrograde patriarchal ideologies in newly established secular institutions. Frustration, coupled with the emergence of a second wave of feminism in Western Europe and the USA, catalysed the surfacing of an almost militant and utopian feminist movement in Quebec. In 1976, Quebec witnessed the emergence of L'Autre Parole, a publication by women who identified themselves as Catholics and feminists and asked for the de-gendering of religious practices and discourses to include the presence and the voice of women. Louky Bersianik's l'Eugelionne, published the same year, parodies sacred male writings, especially the Bible and the writings and theories of Freud and Lacan, satirically denoted as Saint Siegfried and 
Saint-Jacques-Linquant. L'Eugelionne challenges, deflates, and deconstructs androcentric ideology, its sexist discourse and practices, its misogynist reality, and its harmful dichotomies.

Owing to its representational power to encompass physical and sexual difference within the existing patriarchal discourse and to deconstruct negative myths and images, theatre provided feminist collectives with a transgressive and performative space in which to pursue their quest for a female identity. Well known examples of this feminist iconoclastic fervour are plays like Si Cendrillon pouvait mourir (If Cindrella could die) (1975) and La Nef des sorcières (A Clash of Symbols) (1976), which directly attack stereotype female role models.

\section{Quebec decries blasphemy}

On 16 May, 1978, the Arts Council of Montreal informed the director of the Théâtre du Nouveau-Monde, Jean-Louis Roux, about their decision not to fund Les fees ont soif. The president of the council publicly called this play 'a piece of shit', 'trash' and challenged local newspapers to publish three pages of its script. The day after this declaration, La Presse published an extract of the play and by the end of the month, the editor of Devoir, Michel Roy, called for a censor. By June, the debate over the play mobilised public opinion, igniting another Querelle de Tartuffe. ${ }^{3}$ While rehearsals continued, organisations such as the Association of Theatre Directors, the Human Rights League, Quebecois Writers' Union, and the International Institute of Theatre filed petitions against a potential censor. The only female member of the Council, Mme Thérèse Lamarche resigned in protest against the council's decision. On 11 November, when the play was advertised to be staged, the battle seemed won. However, the crusade had just begun. The play premiered on 25 November amidst protests by the extreme right, with reparation vigils organised by the Archdiocese of Montreal and congregations even picketing the theatre en masse to recite the rosary while the play was being performed. Three days later, the Archbishop of Quebec, Mgr. Paul Grégoire, denounced the play for its vulgarity and its frivolous portrayal of the Holy Virgin as 'a puppet, an invention of male domination, a figment responsible for the alienation of women'. ${ }^{4}$

A judicial imbroglio ensued. Following a plea lodged by Emile Colas on behalf of Young Canadians for Christ, Quebecois Catholic Parents' Association, Farmers' Association and the Quebec State Council of the Knights of Columbus, the printed version of the play was banned by the High Court. In January 1979, the decision was reversed on the basis of a technicality and a petition signed by intellectuals, including Simone de Beauvoir, Julia Kristeva, Phillippe Sollers, Denis Roche and Christiane Rochefort. Colas, appealed to the Supreme Court and lost. More judicial proceedings followed until the Supreme Court declared, in 1980, that it would not hear any more cases against the work, stating that 'any injunction against a work of art having considerable social impact, should come from the Public 
Prosecutor of the province, given that the work affects the whole society, not isolated individuals' ${ }^{5}$

Since 1980, Les fees ont soif has been successfully staged several times even during the papal visit to Canada in 1984 - and as recently as July 2005 during the Festival de Fringe in Montreal, without being decried as blasphemous or scandalous. In the literary and in the cultural paradigm, Les fees ont soif is considered as a prominent marker of the post Quiet Revolution assertion of the feminine identity and the social rupture from religious dogmatism in Québec. Why?

\section{Les fees ont soif: feminist iconoclasm and blasphemy}

In his book, Sorcières (1862), French historian Jules Michelet describes fairies as the proud and fantastical queens of Gaul, who brazenly turned their backs on Christ and his apostles and continued to dance. For this impudence, they were imprisoned in containers that would be opened only at the end of time. Drawing on this metaphor in Les fees ont soif (translated by Alan Brown as The Fairies are Thirsty), playwright, Denise Boucher, attempted to deconstruct the role played by myth, image and language in the formation of women's socio-cultural identity by creating an iconoclastic feminine trilogy of the Virgin Mary, the Mother and the Whore as a satirical counterpart to the Holy Trinity of the Father, the Son and the Holy Spirit, to depict how patriarchal tradition has incarcerated women in stereotypical roles of submission. The three characters rebel against their archetypal roles and invite the audience to 'imagine...imagine...imagine' a different world, recreated by women.

In Mythologies, Roland Barthes elaborates how societies create myths to legitimise power structures. ${ }^{6}$ The rapport between power and myth being symbiotic in nature, power creates and legitimises the myth and the myth perpetuates itself while ensuring the official recognition of power. Thus, a myth is, according to Barthes, a social construct which presents itself as natural, but is in fact, fabricated by History through social and cultural conditioning.

More than just a system of theatrical representation, the archetypes of the Virgin, the Mother and the Whore constitute the foundations of an androcentric ideology that has strived to alienate the woman from her own history and her body. The originality of Boucher's play was to create with these archetypes, a functioning trinity capable of denouncing its fears, its deprivations and its stasis.

The Virgin, despite her status as a female religious icon, is more of a feminine model than a feminine creation. The patriarchy accords her power and authority, but only to serve as the model of the perfect, submissive woman. As Julia Kristeva illustrates in her article 'Stabat Mater', 7 the religious and secular representation of femininity in our civilisation is characterised by motherhood - the 
desexualised maternal representation of women - a myth reinforced by the dogma of the Virgin Mother.

Boucher sought to explore not the myth of the Virgin but the wife and mother repressed in her, as she explains in the foreword of her play:

Since childhood, the image of the Holy Virgin walked in my body and my head. The woman hidden in her haunted me. Where would it be possible to meet her?...An entire bachelor culture had projected and transferred its fantasies of virginity on the mother of Jesus and all other women. An androcentric culture had only fabricated a single archetype of reference for women - that of the virgin. A woman who does not enjoy sensual pleasures, be it a mother or a whore. Women are thus exiled from the gratification of their bodies. ${ }^{8}$

A proponent of the same tradition as Kazantzakis, Scorsese and Gibson, Boucher tried to emancipate the Virgin Mary from the conflict between the contradictory elements of the human and the divine that co-exist as part of her personality. Adhering to the iconoclastic conviction that the Divine-Human beings remain essentially divine by overcoming their human impulses and urges and by seeking the 'higher mission' through constant prayer, Boucher induces her character of the Virgin Mary to expunge the divine and embrace the human by rejecting prayer and abnegation from her life: 'Once upon a time, one day... and that is today, I began to distort the Angelus'. 9 'To make a statement, one must come down from the cross' ${ }^{10}$

In the theatrical production, Boucher divided the stage into four distinct areas, offering a representational space to each archetype - Marie, the mother in a kitchen; Madeleine, the whore in a bedroom; and the Virgin Mary as a statue raised on a pedestal towards the back of the stage. In the foreground is the neutral space, a space free from patriarchal influence, where the three characters discover themselves, express themselves freely, and develop their solidarity. More than the depiction of the Virgin, flanked by her supposed alter egos, Marie the wife and mother and Madeleine the whore, it was Boucher's transgression from the terrain of art - or rather her subversive use of art - to attack the overpowering influence of the church on the behaviour of women and the sanctity of the dogmas of the Virgin and the Holy Spirit, that drew the wrath of the clergy.

The statue of the Virgin is portrayed as holding a thick and heavy chain, a parodied representation of the rosary and making a mockery of the Litany of Loreto:

I am an image

I am a portrait

I have my feet planted in plaster 
I am the queen of nothingness

I am the door to an abyss

I am the unconsummated marriage of priests (...)

I am the mirror of injustice

I am the throne of slavery

I am the elusive sacred vessel

I am the obscurity of ignorance (...)

I am the help of the useless

I am the tool of weaknesses

I am the decayed symbol of rotting abnegation

I am more oppressive and more repressing than all words (...)

I am the imagined image

I am she who does not have a body

I am she who never menstruates. ${ }^{11}$

The eternally idolised Virgin leaves her pedestal to occupy the same space as the housewife and the whore, to express her doubts and her aspirations. She agrees with Marie, the mother and wife, about the impossibility of articulating a feminine voice within constraints of a predominantly masculine discourse. Says Marie, speaking to her demented mother:

You who suffered for your subservience, why are you trying to force me into submission as well? (...) you liked the parish priests. They turned you away from your body. From your man. And from me. They robbed you of yourself. (...) They cheated you, mama. Their discourse does not belong to us. It does not possess the vocabulary to express what I feel, what I am looking for. It denies me my identity. ${ }^{12}$

Stepping into the neutral space, the Statue of the Holy Virgin continues:

They profess: 'Silence is golden' in order to crush under their feet, the silent female herds. I too have to shut up so that I can listen to Him always. I owe it to Him to sport the Buddha's grin, the Sphinx's head, the Virgin's eye. ${ }^{13}$

Pushing the limits of decorum and of what was considered as representable in a theatrical production, Boucher not only engages in vulgarising discussion about sexuality, incest and rape, but even involves the Holy Virgin in doing so. Like a frolicsome teenager, the Statue keeps singing repeatedly: 'Someday my prince will come for me'. 14

As an almost shocking sequel to Madeleine the whore's drunken monologue about her depression and her growing aversion to her profession, the Statue moves to the neutral space, chanting a commercial for tampons: 
On those dreary day, lady, thanks to Tantax, feel free! Go horse riding, play tennis, swim! Tantax is discreet. Tantax protects you. Tantax allows you the freedom of movement! Use Tantax! Be modern! Be free! Be Tantax! ${ }^{15}$

The Statue incites the women, Marie and Madeleine, to articulate what was than considered 'unspeakable' and joins them in voicing in a nursery rhyme, their womanly fears of solitude, ageing and independence in a male dominated society:

Statue: Fear

Marie: Fear of going mad.

Madeleine: Fear of being alone.

Marie: Fear of growing ugly.

Madeleine: Fear of becoming too fat.

Statue: Fear of knowing too much.

Marie: Fear of being touched.

Madeleine: Fear of laughing too much.

Marie: Fear of weeping.

Statue: Fear of speaking out.

Marie: Fear of making a fool of myself.

Madeleine: Fear of being a hussy.

Marie: Fear of becoming frigid.

Madeleine: Fear of an orgasm.

Marie: Fear of not having an orgasm.

Madeleine: Fear of being free.

Marie: Fear of my husband.

Statue: Fear of mice.

Statue: Fear. ${ }^{16}$

To reinforce her metaphorical accusation against a system that legitimises the use of abuse as a means of controlling women, Boucher had the actress playing the role of the Holy Virgin, also playing the role of the rapist of the whore and justifying: 'Raping a prostitute does not amount to rape'. ${ }^{17}$

In an almost ironic theatrical twist, the Virgin and Marie take the centre stage to condemn the judiciary and lament the judicial fiasco that ensued as a result of the rapist's trial:

Marie: The trial has all the elements of a masquerade. All the humiliation, all the misery of a dispossessed woman.

Statue: The judge came across as objective. The lawyers as well. None of them felt implicated. (...) None of them recognized in the victim the image of their mother, their daughter or their spouse. Patrimony remained unaffected. As if to say that our heritage permits the rape of women. 
During the trial, the question that aroused the most interest and the anxiety and made us forget even the accused, the question that became the deciding one for the acquittal of the accused was: 'Did the victim resist? ${ }^{\prime 18}$

Some of the lines articulated by the Virgin in this scene are tainted with crude and scandalous sous-entendus about sexuality; for instance, the statue of the Virgin says: 'No matter where. No matter when. No matter how. A tail can thrill. Everyone knows that.' 19

In Luke 12:10, blasphemy against the Holy Spirit is decreed as unforgivable, but Boucher did not consider it as a stumbling block to her feminist iconoclasm - she makes the Virgin call holy prophets 'eunuchs in flesh and mind', 20 deplore her role in the story of creation as the sacrificing mother, call the Holy Spirit a bird, and denote herself as the 'Immaculate of all male obsessions' and the 'queen of the mute':

I was given a bird as a husband. My son was robbed from me through all the ages. He was given a celibate, jealous and eternal father. I was sculpted in marble and made to crush the serpent with all my strength. ${ }^{21}$

Questioning the dogma of the Immaculate Conception is interrogating the dogma of original sin and the virgin birth and amounts to attempting to dismantle the very foundation of the Christian monotheist civilisation. As Leonard Levy demonstrates in Blasphemy, 'The virgin birth was always a likely subject for blasphemous ridicule from Taylor's mad utterances in the seventeenth century, to Paine's sarcasms, to Yeat's "Stick of Incense"". ${ }^{22}$

In the denouement of Les fees ont soif, in which each of the characters rebels against her culturally imposed social role, the Virgin breaks her plaster cast, drops her rosary and releases the serpent, the symbol of sexual desire, a creature cursed by God in the story of Creation, and expresses her disgust of the existing order:

I can't take it anymore. I won't take it anymore. No. No. I don't want this sarcophagus. I don't wish to be worshipped as a statue whilst I am being denigrated, despised and demeaned in every woman. I no longer want to be an alibi for this cursed race of old boys! ${ }^{23}$

Commenting upon the iconoclasm in the play, feminist Claire Lejeune who prefaced the published version of Les Fées ont soif, describes the play as 'a diabolic Sabbath in which the sense of sin and the sacrosanct distance between the mother and the whore are simultaneously lost in public' ${ }^{24}$ 


\section{Defence against allegations of blasphemy}

Elaborating on the characteristics of blasphemy, Lawton points out that those who have set out deliberately to blaspheme, 'set out to argue a system of belief or to commend a way of life, and what is taken to be blasphemy is often, in their view, incidental to their aims or a misrepresentation of them. They tend to feel and say that their words have been taken out of context'. ${ }^{25}$

The creators of the Les fées ont soif always avowed what Bakhtin would call, their 'carnivalesque' aspiration to undermine and destroy the hegemony of Quebecois paternalistic ideology and to elucidate feminine potentials as an alternate conceptualisation of reality. The music composer, Jean-François Garneau, fearlessly affirmed: 'Our entire culture is a culture of celibate men who have rejected women and children through the ages. ${ }^{26}$ Comedians Michèle Magny and Sophie Clement, who played the roles of the Mother and the Whore respectively, publicly asked: 'Up to now, why did our mothers maintain their silence on topics like rape, incest, prostitution and their own self privation of pleasure? ${ }^{27}$ As for the use of coarse language, Boucher deemed it necessary because stereotypes are not easily shattered.

While the Church claimed its 'right to respect' and affirmed its dedication to the emancipation of women, editor of Le Devoir, Michel Roy, expressed the opinion that Boucher could have achieved her objective on the dramatic, lyrical and ideological planes by withdrawing the passages that many believers considered as blasphemous.

The issue of blasphemy normally arises in a community that is divided, and it generally arises because the community is divided. For the readership and the viewers of Les fees ont soif, the boundaries between theatrical representation and reality began to blur. Even for Fr. Emile Legault, founder of the Companions of Saint-Laurent and a strong defender of theatre in Quebec, in a daring television interview praised the play as a 'marvellous theological intuition' but made the following observation:

Five minutes through the play, I began to say to myself that the author was wrong in not presenting to us her characters as clients of a psychiatric clinic. If she had, then the Madonna would not have been the Holy Virgin in person but a mentally disturbed person who thinks she is the Holy Virgin. ${ }^{28}$

Dailies like La Presse reported the angry response from male protesters that the personalities portrayed in the play were a far cry of what their mothers or their sisters were. As for those who practised the oldest profession on earth, they did so 'out of their own free will because it paid fifty dollars a quarter of an hour, better paid than most factories'. ${ }^{29}$ 
And then, of course, there were rejoinders from agnostics, who felt it was time to re-examine the dogma of 'virginity of a mother', 30 and frenzied feminists from the Council for the Status of Women, who accused Quebecoise society of muzzling women and artists radically. Detractors representing this extreme, such as Micheline Carrier, retorted: 'There has never been an occasion for women to interpellate the Church without being reminded to respect the established order, because the Church refuses to engage in a dialogue with women as if to say that the Holy Spirit breathed only upon the male half of humanity. ${ }^{31}$

A study of the religious history of Quebec indicates that the blasphemy law in Quebec, formulated in 1806, is very precise - the most severe form of punishment was, undoubtedly, cutting the tongue of the offender. Drawing on this analogy, Nancy Huston articulates the conclusion of her article on the reception of Boucher's play:

In North America, almost twenty centuries after the birth of Christ, the belief still prevails that — just as the best way to keep a fish from smelling is to cut off the nose - the best way to keep a fairy from being thirsty is to cut out her tongue. ${ }^{32}$

\section{From outrage to acceptance}

The Quebecois society of the 1970s strove to reject Les Fées ont soif from its cultural discourse for its vulgar language and its treatment of then proscribed themes such as menstruation, prostitution, violence against women and women's rage and madness; from the social discourse for its religiously blasphemous import and its virulent onslaught on taboos and myths profoundly anchored in the history of the people; and from the artistic discourse for its amateurish melange of genres like poetry, theatre and opera. However, as is often the case with censorship and succès de scandale, despite its modest artistic quality and its espousal of what now seems to be a utopian cause of the feminism of difference, the play has found a niche in the literary history of Quebec as a daring attempt to create social justice for women by calling for a profound restructuring of society and of the way in which people think and experience the world. By stressing that 'the personal is political', breaking the silence over issues like rape and incest, and, of course, rendering the discourse with much potence by attributing it to the character of the Holy Virgin, this play made the social inequality of women a public and not merely a private problem.

How does one explain the public's nonchalance in the consequent years leading to the present, to the staging of what was once disparaged as blasphemous? Envisioning the humanity of the divine and evoking or expressing it in art is still considered as an attack on conventional piety as we have seen in the public's reaction to Scorsese's The Last Temptation of Christ (1988) or Mel Gibson's The Passion of Christ (2004). It is therefore understandable how a 
recognisably human dimension and an avant-garde feminist depiction of the Virgin as a woman compelled to suppress her corporeal desires, a mother who resents having to sacrifice and grieve for her son in silence in accordance to a higher plan ('I went through this excessive agony of making a child see the light of the day and the darkness of the unknown higher plan. Since I gave him life, I became in many ways responsible for his death as well' ${ }^{33}$ ), and as a rebel who finally breaks away from her role, challenged the beliefs and expectations of the Quebecoise Catholic community.

But with the passage of time, a community that was already divided and in a state of transition gradually lost the importance it accorded to religion as a factor of social cohesiveness. Therefore, an artistic creation that was once considered as morally and spiritually objectionable and had overstepped the metaphorical and ideological limits imposed by the traditional order, did not shock the Quebecois society anymore. The focus of the public has thus shifted from the alleged blasphemous content to the humour and the social message embodied in the play, which Ingrid Pux who played the role of the Virgin in 1995 when the troupe Majeure presented the play, describes as being 'topical because it shows women fossilised in stereotypes'. ${ }^{34}$ Far from being an indictment against men, as it was viewed when it premiered amidst the re-emergence of feminism as 'feminism of difference', for the audience today the play, 'transmits the enduring message that the world can only change when women and men work together to bring about change instead of imprisoning the other in proverbial clichés' ${ }^{35}$

I must confess, however, the moral conflict that assailed me while writing this chapter. Boucher's depiction of the Virgin scandalised me, for, as a Catholic, I have always revered the Holy Virgin for her emancipatory role in the history of redemption of Mankind. As a daughter, a wife and a mother, I look up to her not as a servile instrument in the fulfilment of a greater plan but as a role model exemplifying dedication, fortitude and courage — she is one of the reasons why I feel privileged to be a woman. Despite my reservations and my personal religious convictions, as a Bakhtinian, I laud Les fées ont soif for its artistic iconoclasm, which induced society to reconsider and re-evaluate its attitude towards women; and for its heteroglossic capacity to reflect a multitude of dissenting voices in a dialogic relationship, interrogating the predominance of a single repressive ideological discourse.

\section{Endnotes}

\footnotetext{
1 David Lawton, Blasphemy, 1993, Philadelphia: University of Pennsylvania Press, p. 139.

2 In Les religieuses sont-elles féministes?, Micheline Dumont speaks about the increase in the number of Quebecoise nuns (from 1850 to 1965, an increase from 650 to 43,274) and explains that taking orders was a form of individual emancipation, that the Church provided women who became nuns with an access to life which the Quebecoise society would have otherwise denied them. Micheline Dumont, 1995, Les religieuses sont-elles féministes? Montreal: Bellarmin.
} 
${ }^{3}$ Querelle de Tartuffe (1693-94). As evidence that the clergy in the New World could be as controlling as that of the Old, the Church banned the proposed production of Molière's Le Tartuffe. Even 30 years after its creation, the play was still considered controversial in France. In the New World, the controversy was more of a battle of power between the state and the clergy than a battle over morality.

4 Lise Gauvin, 'Introduction', in Denise Boucher, 1989, Les fées ont soif, Montréal: l'Hexagone, p. x. For a more recent version of the play, see Denise Boucher, Les fées ont soif, Éditions Typo, 2008. This play has also been translated in English by Alan Brown as The Fairies are Thirsty, Talonbooks, 2008. This translation can also be found in the Anthology of Québec Women's Plays in English Translation, Volume I (1996-1986), (edited by Louise H, Forsyth) Playwrights Canada Press, Toronto, 2006. An English translation can also be found in Plays by French and Francophone Women: A Critical Anthology (edited and translated by Christiane P. Makward and Judith G. Miller with an annotated bibliography by Cynthia Running-Johnson) The University of Michigan Press, 1994.

5 Ibid., p. xi.

6 Roland Barthes, 1957, Mythologies, Paris: Seuil.

7 Julia Kristeva, 1985, 'Stabat Mater', Poetics Today vol. 6, no. 1-2, pp. 133-152.

8 Boucher, op. cit., p. 39.

9 Ibid., p. 46.

10 Ibid., p. 52.

11 Ibid., p. 60.

12 Ibid., p. 77.

13 Ibid., p. 85.

14 Ibid., pp. 47, 48.

15 Ibid., p. 53.

16 Ibid., p. 53.

17 Ibid., p. 92.

18 Ibid., p. 93.

19 Ibid., p. 93.

20 Ibid., p. 77.

${ }^{21}$ Ibid., p. 50.

22 Leonard Levy, 1993, Blasphemy, New York: Alfred Knopf, p. 534.

23 Boucher, op. cit., p. 95.

24 Levy, op. cit., p. 28.

25 David Lawton, 1993, Blasphemy, Philadelphia: University of Pennsylvania Press, p. 2.

26 Jean-François Garneau, 1978, Texte liminaire de l'édition originale, Intermède quoted by Lise Gauvin, 'Introduction', in Denise Boucher, 1989, Les fées ont soif, Montréal, l'Hexagone, p.10.

27 Garneau, op. cit.

28 Legault, quoted in Edmond Robillard, 1978, 'Forum des lecteurs' Le Devoir, 18 December (my italics).

29 E. Robillard, 1978, 'Opinions', La Presse, 15 December.

30 Bernard Larivière Saint-Colomban, 1978, 'Arts et Spectacles - Lectures', La Presse, 15 December.

31 Micheline Carrier, 1978, 'Forum des lecteurs', Le Devoir, 28 December.

32 Nancy Huston, 1981, 'Blasphemy in “Nouvelle France" Yesterday and Today', Maledicta, vol. 5, no. 2, pp. 163-169.

33 Boucher, op. cit., p. 83.

34 As reported by Renée Larochelle in her preview, “"Théâtre. Les fées ont soif”. Au fil des Événements", Université Laval', dated 12 October 1995 of the performance to be staged on 13 and 14 October, 1995, at Café theatre des Fourberies. http://www.scom.ulaval.ca/Au.fil.des.evenements/1995/45/011.html (Viewed 26 August 2008.)

35 Larochelle, op. cit. 